\title{
IDEOLOGY AND FACULTY SELECTION
}

\author{
JUDITH JARVIS THOMSON*
}

I

The first statement on academic freedom by the then-new American Association of University Professors ("AAUP") was its 1915 Declaration of Principles, ${ }^{1}$ which said that a university

should be an intellectual experiment station, where new ideas may germinate and where their fruit, though still distasteful to the community as a whole, may be allowed to ripen until finally, perchance, it may become a part of the accepted intellectual food of the nation or of the world. ${ }^{2}$

The purposes for which our society establishes such institutions are, as the declaration said, threefold: the advancement of knowledge, the provision of higher education for students generally, and the training of specialists in the various professions. Such institutions therefore play a crucial, central role in the nation's cultural and economic life, for it is in them that the nation's future is born. To the extent to which they do not welcome new ideas, their threefold purposes cannot be well accomplished, and the future that grows out of them is stunted. As the AAUP's later 1940 Statement of Principles on Academic Freedom and Tenure put the point, in brief: "Institutions of higher education are conducted for the common good [, which] depends upon the free search for truth and its free exposition."3

But on some views, institutions of higher education are failing to serve as intellectual experiment stations: they are charged with behaving like homes of orthodoxy, reaction, and conventionality. Feminists complain that institutions of higher education are dominated by male-inspired conceptions of what constitutes good scholarly work, and that the content of teaching makes women's lives and women's work at best invisible. Feminists are joined by scholars in Afro-American Studies in complaining that the literary canon these institutions place before their students is at best arbitrarily restricted to the products of white males-I say "at best arbitrarily," since on some views the canon is a product merely of white male bigotry. Some people complain that the philosophical canon these institutions place before their students is improperly restricted to the products of Western philosophy, totally ignoring

Copyright $\odot 1990$ by Law and Contemporary Problems

* Professor of Philosophy, Massachusetts Institute of Technology.

1. AAUP, Declaration of Principles (1915), reprinted in L. Joughin, ed, Academic Freedom and Tenure: A Handbook of the American Association of University Professors, App. A, at 157-76 (Univ of Wisc Press, 1969) (“1915 Declaration”); see Appendix A, 53 L \& Contemp Probs 393 (Summer 1990).

2. 1915 Declaration at 167-68; Appendix $A$ at 400 (cited in note 1).

3. 1940 Statement of Principles on Academic Freedom and Tenure, in Policy Documents and Reports 3 (AAUP, 1984) ("1984 AAUP Red Book"); see Appendix B, 53 L \& Contemp Probs 407 (Summer 1990). 
the East; and some complain that even within Western philosophy, it is nowadays not possible for nonanalytic philosophical work to get a hearing on campus.

From a different direction come complaints to the effect that left-wing politics and commitments now dominate college and university faculties, and that institutions of higher education are behaving like homes of left-wing orthodoxy, so that conservatism cannot get a hearing on campus. From yet another direction come complaints that colleges and universities are the homes of relativism and nihilism, and that serious work aimed at discovering and teaching moral and political truths is made unwelcome there.

This kind of complaint-and I have mentioned only a small sample-is not new. Some twenty and thirty years ago the orthodoxy complained of was right-wing: it was charged that colleges and universities were not opening their doors to the ideas of the left, and that Marxist economics and Marxist social theory could not get a hearing on campus.

It is of interest that the 1915 Declaration went directly on to say:

Nct less is it a distinctive duty of the university to be the conservator of all genuine elements of value in the past thought and life of mankind which are not in the fashion of the moment. Though it need not be the "home of beaten causes," the university is, indeed, likely always to exercise a certain form of conservative influence. For by its naiure it is committed to the principle that knowledge should precede action, to the caution (by no means synonymous with intellectual timidity) which is an essential part of the scientific method, to a sense of the complexity of social problems, to the practice of taking long views into the future, and to a reasonable regard for the teachings of experience. One of its most characteristic functions in a democratic society is to help make public opinion more self-critical and more circumspect, to check the more hasty and unconsidered impulses of popular feeling, to train the democracy to the habit of looking before and after. ${ }^{4}$

But this obviously cannot be understood as supplying a rationale for the rejection of new ideas. The authors of the declaration said "a reasonable regard for the teachings of experience," not a willful refusal to be open to new experience, and the passage is best understood as a prescription that the university should not flutter in the winds of changing current fashion, which is entirely compatible with the prescription that the university should not allow itself to be dominated by the orthodoxy of a past fashion.

Complaints that institutions of higher education fail to welcome new ideas have to be taken seriously, since we all suffer in the long run to the extent to which they fail to do so. The wide attention such charges generate in the public at large is testimony to public recognition of that fact. I will not even try to assess the correctness of any of these complaints, either those being made nowadays or those that were made some twenty and thirty years ago. The AAUP's Committee A on Academic Freedom and Tenure has only recently begun to confront these issues directly, ${ }^{5}$ and what I take on is the

4. 1915 Declaration at 168; Appendix A at 400-01 (cited in note 1).

5. Committee A's current interest was triggered by an inquiry it received in 1984 from a law school professor. Committee A responded briefly to the general question this letter raised in Some Observations on Ideology, Competence, and Faculty Selection, 72 Academe la (January-February 1986), and 
modest task of asking, on the one hand, whether it might not be useful to make some distinctions, and, on the other hand, whether anything useful can be said at a very general level about what kind of defense against such charges is available-when it is available. I will focus on an institution's selection of new faculty, not reaching the further questions that arise when what is in the offing is reappointment or the award of tenure.

Faculty selection calls for decision at two levels. There is, first, the decision about which field (area, discipline, specialty) to hire in; once the first decision has been made, there is, second, the decision about which candidate in the relevant area to hire.

We are a college, and an alumna offers us funds for an endowed chair, the field of expertise unspecified. What shall we devote the chair to? Well, what are our needs, and which is most pressing? We look around us and conclude that our offerings in history are weak, particularly in American history. On the other hand, while we have three faculty members in philosophy, we have no one who is trained in Greek philosophy. But it is also true that we have no department of computer science; we could devote the chair to that field and divert funds from mathematics and classics to contribute to the building of the new department. And so on.

A decision on this matter rests on three kinds of judgment. In the first place, there is the obvious question of cost. Any appointment, at any level, imposes costs on the institution, and I do not mean merely the opportunity costs of forgoing someone or something else. Building a new department of computer science, for example, would be a very expensive affair, requiring both additional new faculty and an investment in equipment and laboratory space. Even expanding our offerings in American history might not be without further cost: it would, at a minimum, require expanding the library's holdings if the person appointed specializes in a different area from those of the faculty members who currently teach American history here.

In the second place, and more interesting for present purposes, we may need to ask ourselves the deep question what kind of institution we are. What really is our educational mission? What are we trying to do for those who are currently our students? What do we want to be able to do for those we would like to encourage to become our students in the future? What we see as our needs will be constrained largely by our views about the answer to this question, even if we do not find ourselves provoked into asking it explicitly.

Largely, but not wholly; for there is an in some ways still more interesting third question that lurks here: which fields are themselves worthy of longterm investment? This question is immediately relevant for a university in

to the specific question about law schools in its report for 1985-86, Report of Committee A, 1985-86, 72 Academe 13a, 18a-19a (September-October 1986). The present article may be regarded as ruminations on the issues dealt with in those two policy statements. 
light of its direct commitment to the advancement of knowledge. But the question arises even for four-year colleges, since the question whether work in a field is of scholarly importance, and, if so, of what kind, bears on the question in what way, and therefore whether, an investment in it would contribute to the college's fulfilling its educational mission. Fields within academic disciplines, and even academic disciplines as a whole, wax and wane in interest over time. Forty years ago, linguistics was a quiet enterprise, tucked into the average school (if on campus at all) in its department of English or foreign languages and literatures; nowadays it thrives on campuses across the country in departments of its own. Even more striking has been the stunning growth of computer science on campuses. By contrast, departments of education have shrunk, and at some schools have disappeared altogether. When it looks at its offerings and asks itself what it needs, a school cannot avoid making a judgment about which fields are worth investing in, given its purposes.

In the case of some fields, the answer is easy. "Look," we might be told, "astrology is booming nowadays: all manner of new ideas are being developed. And doesn't the AAUP say that an institution of higher learning should be an experiment station, where new ideas may germinate?" We may be excused if we do not regard ourselves as obliged to supply germination space for what goes under the name "new ideas in astrology."

Why may we be excused for this? Because it is obvious that there is no future in those new ideas.

But there is something worrisome about this reply. Isn't "it is obvious that there is no future in those new ideas" the very voice of the defender of an orthodoxy?

No one, in fact, worries about the absence of astrology in college and university offerings: no one charges them with being homes of orthodoxy in light of their not including it. But suppose someone did. It pays to ask what we could reply in defense of ourselves. Astrology should, after all, be an easy case, and attention to it should therefore help us to see what is in question in harder cases.

So let us suppose that we are the college's committee, charged with recommending to the college at large a disposition of the new chair. We decide to begin with an open house: everyone is invited to come in with suggestions. Someone who attends the open house suggests that we devote our chair to astrology. In our later, private, discussions, we trouble to vote on all suggestions, and we vote against astrology. Word of this gets out, and the friend of astrology requests a hearing before us, at which he says, "New ideas ... AAUP ... germination space ... defenders of orthodoxy!" What do we reply? Well, we say that there is no reason at all to think that the planets and stars influence the ordinary lives of ordinary people. Sometimes what an astrologist predicts does, in fact, happen: my horoscope for last Wednesday said that I would meet a tall, dark man that day, and I did. But, on the one hand, what an astrologist predicts very often does not happen, and, on the 
other (even more important) hand, there is no reason to think that it is because of events in the heavens that an astrologist's predictions turn out to be true when they do.

What we do, in short, is to put it to the friend of astrology that astrology does not meet even the minimal standard an enterprise must meet if it is to count as a science, namely that there should be reason to believe that its theories explain the truth of its predictions when they are true.

But the friend of astrology is not without a reply. Most likely he will make a variety of allegations of fact that would, if true, give reason to believe that it is because of events in the heavens that an astrologist's predictions turn out to be true when they do. If he takes this line, he is arguing that astrology really does meet the standard we said that an enterprise must meet if it is to count as a science.

Alternatively, he may argue that this standard should be rejected: that it is neither here nor there whether astrology meets this standard, because an enterprise need not meet it in order to count as a science. This reply is less likely, however, since it is the respectability of the label "science," interpreted as we interpret that label, that friends of astrology would like the enterprise to be thought to deserve.

Let us postpone consideration of those two possible replies. We should now look rather at the following third possible reply that he might make: "Prove it!" It is important to stress that this reply will not do at all.

To begin with, could we prove that astrology fails to meet the minimal standard, and therefore is not a science? Perhaps you could, but I can't. I can't even do much in the way of formulating an argument. I believe that the motions of the heavenly bodies do not influence the everyday affairs of ordinary people, but on what ground do I believe this? My believing it is a product of a vague, loose conception of how the world works and of what causality involves and requires, picked up over the years from experience (which includes some snippets of science I have become acquainted with), and there is nothing I can produce in the way of compact, clear argument for my belief. Perhaps one of my colleagues in our physics department could do better than I can (I am, let us suppose, a member of the English department), but I say only perhaps, because demonstrating that the motions of the heavenly bodies do not influence the everyday affairs of ordinary people is not a task that the average physicist has ever thought of carrying out, and it is not obvious how he or she is to do so.

Does that mean that I acted improperly in voting against astrology? I should think not. To suppose it does is surely to indulge in excessive highmindedness about what responsible decision-making requires. Since my belief really did issue from a conception of how the world works, acquired from past experience, I need not be capable of proving that there is no future in astrology in order to have acted responsibly in rejecting it.

Indeed, it would have been irresponsible for me to have acted otherwise. For what were my alternatives? To abstain from voting? To suggest we flip a 
coin? To suggest we turn the decision-making over to some other person or group? None of these alternatives would have been as good. As a member of the committee, I was under a duty precisely to bring my past experience to bear on, among other questions, the question what fields are worth investing in. Given my past experience, I would have failed in that duty if I had refrained from voting against astrology.

The friend of astrology is now before us, however, at the hearing he requested, and we can reverse ourselves. But if, in reply to our assertion that astrology fails to meet the standards required of a science, he merely says "Prove it!", there is no ground for complaining of our behavior if we do not reverse ourselves. If he gives no reason to think we were mistaken when we first took our vote, everything remains as it was. His saying "Prove it!" can on no view be thought to shift the burden of proof to us.

The point here is worth stress: new fields, indeed, new ideas generally, have the burden of proof. And it might be worth noting also the connection between this point and that "conservative influence" the 1915 Declaration said the university is likely to exercise. By its nature, as the declaration says, a university is committed to caution, and to "a reasonable regard for the teachings of experience." 6 We fail to display that reasonable regard if we suppose that we are not entitled to act on beliefs based on past experience unless we can prove them true. No doubt some of those beliefs may be mistaken, and I will draw attention to an example shortly; it is fair to say, more strongly, that none of those beliefs is immune to revision later. But in the absence of reason to think revision is called for, responsible decision-making does not merely allow, but calls for relying on them.

As I said, however, it may be that the friend of astrology will not say "Prove it!": he may instead make the first or second replies to which I draw attention. On the one hand, he may make allegations that would, if true, give reason to believe that it is because of events in the heavens that an astrologist's predictions turn out to be true when they do. On the other hand, he may argue that that standard should be rejected: he may argue that an enterprise need not meet that standard in order to count as a science. Whichever line he takes, he is picking up the burden of proof, and there will then be room for debate about whether he is carrying it. I do not say that he cannot (I do not suppose that astrology is self-contradictory); I say only that he must.

A second important point is that he has not carried his burden of proof by virtue of saying just anything at all. (For example, he has not carried it if he has offered us in evidence of the powers of the stars only that they sing to him at full moon.) His carrying the burden requires his producing what we-given our past experience-can see to be reason to revise our beliefs. For what is in question is whether we would be acting responsibly in refusing to reverse ourselves-not whether an all-knowing God would, but whether we would.

6. See note 4 and accompanying text. 
This means that our acting responsibly in refusing to reverse ourselves is entirely compatible with our being mistaken.

New ideas have occasionally been rejected by the respectable academic audiences to whom they were first presented and later turned out not merely to have been right, but to be of the greatest scholarly importance. Perhaps the most striking recent example is the discovery by Barbara McClintock of transposable genetic elements in maize. She first presented that work in the early 1950s, but was met at the time by bewilderment and therefore lack of interest, and it was not until many years later that the importance of the work was recognized: she received the Nobel Prize for it in 1983. The example is particularly striking because Dr. McClintock was not a struggling young graduate student in the early 1950s; she was by then a distinguished biologist who had in 1944 become the third woman elected to the National Academy of Sciences, and in 1945 served as president of the Genetics Society of America. How could the ideas she presented in the early 1950 s have been so roundly rejected at the time? An academic career is built on a battery of deep intellectual commitments, and it is arguable that the respectable biologists who rejected her ideas were being improperly (because excessively) protective of their own commitments: accepting her new ideas would have required a major revision in those commitments.

It is also arguable, however, that there was no impropriety in the rejection of those ideas, and that the ideas simply were at the time too new and unconventional to be absorbable into the biology of the time. Absorbing a body of new ideas into a science requires finding theoretical room for them: theoretical connections must be made between the new and what it is important to preserve of the old-and what it is important to preserve of the old becomes clear only when those connections are made. ${ }^{7}$

What we learn of, of course, are the instances in which the initially rejected new ideas finally came to prevail. It is certainly possible that other new ideas have sunk without a trace because their discoverers did not have the selfconfidence and stamina (to say nothing of the funds) to carry on with their work despite rejection.

But the question is, what conclusion should be drawn from actual examples such as that of McClintock, and the possibility of other, equally

7. Stephen Jay Gould also suggests that McClintock's own personal style may have contributed to the rejection of her ideas:

McClintock has always worked for herself and in her own way, never tailoring her efforts to win acceptance, or even to promote understanding among those who might need a little extra prodding or clarity to appreciate an unconventional notion. [S] he never did all she could to promote her chances in the admittedly tough battle for acceptance and understanding of transposable elements.

Stephen Jay Gould, Triumph of a Naturalist, reprinted in Stephen Jay Gould, ed, An Urchin in the Storm: Essays About Books and Ideas 164 (W.W. Norton, 1987). Gould's Triumph of a Naluralist is a review of Evelyn Fox Keller, A Feeling for the Organism: The Life and Work of Barbara McClintock (W.H. Freeman, 1983). That a scientist has to work to get his or her new ideas accepted stems from the fact that the new has the burden of proof. And see note 8 .

I am indebted to Mary C. Potter for the McClintock example and the reference to Gould's essay. 
important, new ideas that were mistakenly dismissed and did not in the end prevail? It could hardly be concluded that the assessment of new ideas-for example, in deciding which to fund further research on-should be taken out of the hands of currently respected experts and turned over to people outside the field. With the best will in the world, currently respected experts may get things wrong; outsiders might be so far lucky as to get things right, but if they do then that is mere luck.

It is not easy to say what constitutes making such assessments with, as I put it, the best will in the world. It is easy enough to say that the assessment must be made with due care, and not on grounds irrelevant to scholarly values. Obvious examples of assessments made on grounds irrelevant to scholarly values are those based on the sex, race, or politics of those who profess the new ideas. Again, a person who makes a negative assessment of new ideas because their coming to prevail would result in his or her losing status-his or her position of distinction in the field and the research funds it attracts-is also, obviously, making the assessment on grounds irrelevant to scholarly values. But it is likely to be a delicate matter whether an assessment really is being made on irrelevant grounds, for academics are rarely conscious villains: where nonscholarly values are at work, this is likely to be unconsciously or only semiconsciously so.

Moreover, love of one's own commitments may not issue merely from love of one's own status, and there is much that is good in it-compare that "conservative influence" to which the 1915 Declaration drew attention and the fact that the new has the burden of proof.

This connects with one source of the difficulty of defining due care. It won't do to say that the degree of care required is in proportion to the importance of the purpose for which the assessment is being made. Time itself is a scarce resource, and the degree of care that is due is surely a function not merely of the importance of the task for which the assessment is being made, but also of what the assessors take to be the degree of inherent implausibility of the new ideas and the time it would take to investigate whether their attribution of implausibility is mistaken. This is among the reasons why the absorption of new ideas in science may be sluggish, and the more sluggish, the more unconventional the new ideas are: replicating the work that issued in the new ideas, and then studying their further implications, takes time, and the scientist's colleagues need to be convinced that the time would be spent profitably. ${ }^{8}$

There is such a thing as excessive love of one's own commitments, of course, even where what lies behind it is concern for the truth and not merely for status, but the signs of it are likely to be delicate. I have in mind the thinking of people who know of data that appear to conflict with their theories, but do not take seriously enough the task of confronting the data.

8. And this is among the reasons why the scientist has to work at the enterprise of getting his or her new ideas accepted. See note 7. 
(How seriously is seriously enough? That is hard to say. There are times when it is right simply to plow ahead, hoping that the apparent conflicts can be sorted out later.) Or the thinking of people who know of data that appear to conflict with their theories, and construct excessively ornate procedures for squaring the data with the theories. (There are epicycles in nature; which postulated epicycles are excessively ornate?) I talk here of "data," but scientists are plainly not the only ones who may behave in this way: any academic may.

It is clear, in any case, that while the new has the burden of proof, and the proof required is proof to the assessor, the assessor must exercise due care and must make his or her assessment on scholarly grounds, without excessive love for his or her own commitments. But having carried out that duty is compatible with having reached the wrong assessment.

I began by inviting you to imagine that we are a committee charged with making to the college a recommendation as to the disposition of its new chair, and I pointed to the fact that doing so will involve our asking ourselves which fields are worthy of a long-term investment. Asking about a field differs only in degree from asking about a new idea, for a field is just a set of more or less tightly interconnected ideas that generate a set of research programs and a methodology for carrying them out. So, similar conclusions hold of our enterprise. It pays to mention, however, in light of the considerations just attended to, that we must be sure to have among us members who possess some expertise in the fields available to us for choice, or who are capable of advising us of ways to acquire it in what we can see to be hard cases.

Astrology is an easy case. Our principled defense against the charge that in rejecting it we have refused to welcome new ideas and behaved like defenders of an orthodoxy lies in nothing more arcane than the fact, if it is a fact, that we have exercised the appropriate degree of care in assessing it, and have made our assessment on scholarly grounds, without excessive love of our own commitments. What marks astrology as an easy case is the fact thatgiven our own past experience-the appropriate degree of care is no care at all. We are entitled to dismiss it out of hand.

I am sure you think the same holds of creationism. What about feminist epistemology? Some people think that is not a field of study at all, but mere politics masquerading as theory. Some people think that the ideas central to Marxist economics, or for that matter, central to supply-side economics ("voodoo economics"), have no more place on a campus than do those central to astrology. The same point holds if committee members vote against giving these ideas a place on campus: they have a principled defense against the charge that they are refusing to welcome new ideas and behaving like defenders of an orthodoxy to the extent to which they have made their assessment in the way I described. 


\section{III}

The people I just mentioned think that those ideas have no place on campus at all: they would not have them among their offerings even if unlimited funds were available. Why so? Why not live and let live, so long as there is no shortage of funds? Where, as at most colleges and universities, the faculty as a whole has a major say as to the academic program its school offers, and decides to whom the school's degrees will be awarded, the faculty stands behind its school's offerings to this extent at least: it certifies that (in its view) the program is academically respectable. ${ }^{9}$ If we think that astrology or feminist epistemology or Marxist economics (or what you will) are not academically respectable enterprises, we will not want them included in our school's offerings at all: we will not want a student's courses in those subjects to count toward the degrees our school awards.

Others, however, may think that those enterprises do have a place on campus, but not at the cost of forgoing other enterprises. That is, they may be quite content with the thought of work in those areas counting toward the degree, but think that-given limited funds-the school has other, more pressing needs.

Decisions made on this kind of ground are familiar enough. We might be entirely content, perhaps even happy, with the thought of our college acquiring an anthropologist, a teacher of Greek, a specialist in Chinese history, even a specialist in the history of astrological literature, while also thinking that what we need more pressingly is a computer scientist, a specialist in Greek philosophy, or a specialist in American history.

It might be worth making a distinction here. We may consider some subjects to be of great inherent interest and importance, and reject them only on the ground that, given our educational mission, it is less important for us here at Such and Such College that they have a place on campus. Anthropology, for example. Or the history of astrological literature. (We might even think that a study of that literature could shed fascinating light on the history of culture and of science.) In rejecting those enterprises, we imply nothing invidious about work done by those engaged in them. Our rejection issues wholly from a conception of our educational mission and of what is required for carrying it out.

We may consider other subjects to be of some inherent interest and importance, and reject them on mixed grounds: on the one hand, the belief that they are of less general interest and importance than other enterprises, on the other hand, the belief that, given our educational mission, it is less important for us to have them on campus. Marxist economics, perhaps. Or feminist epistemology.

9. It is often said that an institution of higher education must be neutral, placing itself on neither side of a disputed claim to truth. The underlying thought here must surely be right. But what exactly is the underlying thought? Colleges and universities do, after all, quite properly declare themselves on the substantive question of what constitutes work worth giving academic credit for. See also note 14 and Part VIII. 
Our views about the relative interest and importance of the various fields are like our views that this or that (putatively) scholarly enterprise is not a scholarly enterprise at all: we have a principled defense of them just to the extent that we have exercised due care in arriving at them, and have made them on scholarly grounds, without excessive love of our own commitments.

Similarly, for our view about our educational mission. Are we defenders of an orthodoxy-an orthodoxy here about what our institutional aim should be-in refusing to alter it so as to make room for enterprises not currently on campus? We may have a similarly principled defense of our refusal to do so.

Discussions of this kind are fairly common on campuses. Swings in views of the relative importance of scholarly disciplines do take place; compare the shifts I mentioned in views about the importance of linguistics and education. But discussions about educational mission have become even more common in the last forty years and have captured the attention not merely of the faculty and students on campus, but of the wider public as well. During the 1950s people said "Tighten up!" (Remember Sputnik.) During the 1960s people said "Loosen up!" During the 1980s people said "Tighten up!" I am sure that throughout the nineties people will be saying both: loosen up here and tighten up there.

It goes without saying that reasonable people both on and off campus will disagree with the conclusions we reach at Such and Such College, whether about assessments of fields or educational mission. And different schoolseven different schools that hope to attract similar student bodies-will therefore offer different programs. But that can hardly be regarded as ground for complaint; quite to the contrary, it is a sign of health in the nation's educational system that it allows for these differences. I may think your views on such matters grossly mistaken, idiotic in fact, and you may think the same of mine; we should both welcome the variety in institutional programs that grows out of our differences.

\section{IV}

Having decided which field to invest in, a school is then confronted by candidates for its position, and each will have a battery of attitudes and beliefs. Hiring decisions are very strongly affected by the candidates' attitudes and beliefs, and there is room here for yet another charge of refusing to permit entry to the new.

Of course a candidate's attitudes matter: they matter because they bear on how he will behave on campus, which itself matters because it bears on his suitability for the position the school wishes to fill. To the extent to which we have reason to think a candidate feels contempt for blacks or Jews or women, for example, we have reason to think he will not behave fairly with others, whether students, colleagues, or anyone else the holder of the position will have to deal with. This point is not limited to what are most commonly thought of as prejudices. Consider, for example, arrogance and impatience. Sneering at and humiliating students may not be the worst of academic sins, 
but on most views it is among the worst; sneering at and humiliating one's colleagues is something they may be willing to put up with in exchange for sufficient brilliance, but it is risky, given the need for cooperation in carrying out the department's work. Indeed, the department's joint work may not be the only thing that suffers from the presence of the excessively arrogant: bullying and intimidation can chill independent thinking, especially in the less secure junior members of the department. ${ }^{10}$

An attitude that we have reason to think will cause unacceptable behavior on campus may be, as we might put it, belief-driven. What $I$ have in mind is the possibility that a candidate's contempt for Jews, for example, issues from his believing that Jews are greedy and dishonest. (Of course it may instead be that the belief is attitude-driven, or that attitude and belief developed together, circling round and reinforcing each other.) That the attitude is belief-driven in no degree protects it, however: if the candidate's attitude gives us reason to think he will behave unacceptably on campus, then the fact that his attitude is belief-driven makes his harboring it no less reason to think so. That is so even if the belief that drives his attitude is true.

For another kind of example, consider the candidate who makes clear that he feels contempt for those who hold certain views widely accepted in the field. His contempt might be-indeed, is likely to be-belief-driven: he is likely to feel it because he believes that the views are grossly mistaken. The belief that drives his contempt might cut more deeply: he might believe not merely that the views are grossly mistaken, but that the very standards that are commonly thought to justify them are the wrong standards. Or the belief that drives his contempt might cut more deeply still: he might believe not merely that the views are grossly mistaken, not merely that the standards thought to justify them are the wrong standards, but that it is a gross mistake to think that there can be standards for the acceptability of views in the field. This does cut more deeply, for it says that those in the field are mistaken not only in thinking that reasoning in such and such a way is rational, but in thinking that there are any constraints of rationality at all governing the field-one who believes this believes that no assertion in the field can be any better supported by reason than its negation can, and that the only "good" argument in the field is the argument that convinces, there being no room for the further question whether anyone ought to be convinced by it. We might give the name nihilism to this belief.

Those who work in the natural sciences may wonder how anyone could put himself forward as a candidate for a faculty position in a field-how anyone could wish to spend his life teaching and conducting research in a field-if he is a nihilist about the field. But if they feel puzzled, that just shows they have

10. Paul Carrington draws attention to the importance for academic freedom itself of an institutional ambiance that encourages intellectual risk-taking, and to the need for mutual respect and restraint in generating that ambiance. See Paul D. Carrington. Freedom and Community in the Academy, 66 Tex L Rev 1577 (1988). 
led sheltered lives. Nihilism is a going concern in the humanities, in literary theory, for example, and in philosophy.

It is also a going concern in legal theory. Some years ago, Dean Paul D. Carrington argued that those who profess "legal nihilism" have "an ethical duty to depart the law school, perhaps to seek a place elsewhere in the academy," nihilism" is a belief about law of the kind I pointed to, namely the belief that no assertion in the law can be any better supported by reason than its negation can. ${ }^{12}$ The people he had in mind are members of the Critical Legal Studies movement, and many of them do appear to hold this belief. ${ }^{13}$

Suppose the candidate for our position does feel contempt for those who think there are standards governing reasoning in the field, and that his contempt is belief-driven by nihilism about the field. The fact that his contempt is belief-driven does not protect it, even if nihilism is true. If, for example, we have reason to think that his attitude will issue in unfair treatment of others, or in bullying or intimidation, we have, to that extent, reason to think he is not suitable for our position.

\section{V}

Are there any beliefs such that a candidate's having them by itself disqualifies him? We need to distinguish. In the first place, it might be said that some beliefs are such that anyone who holds them may be expected to behave in unacceptable ways on campus. Some people think that those who believe that communism supplies the truth about political, economic, and social matters would not engage in or allow students to engage in free inquiry. (Some think the same of those who believe that anticommunism supplies the truth about those matters.) Some think that those who believe that blacks are

11. See Paul D. Carrington, Of Law and the River, $34 \mathrm{~J}$ Legal Educ 222, 227 (1984). It was this article that provoked the law professor's inquiry about the AAUP's position on the use of ideological considerations in faculty selection at law schools. See note 5.

12. I say only that this is plausible, for some things Carrington says suggest that he meant something different by "legal nihilism." He does say that "the nihilist" professes "that legal principle does not matter," id at 227, which suggests that my interpretation in the text above is correct. But he also says that the people he has in mind cast doubt on the idea "that legal principles actually influence the exercise of power," id, which is not the same-you might well think that some assertions in law are better supported by reason than their negations are, while at the same time thinking that those in power have acquired and retained their power by something other than reason. A historical thesis is one thing, a thesis about the nature of law quite another. But I do not think this unclarity unique to Carrington: I think it may be fair to say that some members of the Critical Legal Studies movement have not themselves always been sensitive to this difference.

13. Here, for example, is Robert W. Gordon:

[B]ecause [law] is founded upon contradictory norms, its principles cannot constrain a single set of outcomes even if intelligently, honestly and conscientiously applied. In contract law, for example, there is always a legitimate argument for maintaining one party's freedom of action and a contrary argument for protecting the other party's security; for every argument for enforcing the deal . . . there is a counter-argument for voiding the deal. Robert Gordon to Paul Carrington, in "Of Law and the River, " and Of Nihilism and Academic Freedom, 35 $\mathrm{J}$ Legal Educ 1, 2 (1985) (emphasis in original). That counterarguments are always available is not an interesting thesis, so I take Gordon to mean something stronger, namely that equally good counterarguments are always available. See id. 
on average genetically inferior to whites in intelligence would behave dismissively toward blacks on campus. Some think that those who accept nihilism would engage in bullying and intimidation.

Again, some think that the holders of this or that belief would use their classes as opportunities for proselytizing on matters extraneous to the subject, or would omit material which the department requires its students to become familiar with. ${ }^{14}$

On the other hand, these expectations-all of them-may just be false. For example, it is entirely possible for a person to believe that blacks are on average genetically inferior to whites in intelligence without behaving dismissively toward blacks on campus. For another example, someone who is a nihilist about a given field may treat those he thinks deluded with great respect; and he may be happy to dwell on their work in all suitable detail in his classes, if only because the more worthy the work of the people one is criticizing, the more impressive one's demonstration of their mistakes.

There are closer cases. What, for example, of those who believe that only the politically acceptable are entitled to freedom of speech on a college or university campus? Doesn't their holding that belief give us reason to think they would try to prevent, and incite others to try to prevent, the politically unacceptable from speaking on campus? Yes; and I think we may take them to have the burden of explaining why we should not think they would. All the same, explaining away the appearance is possible: for example, their belief might be a matter of political theory and not something they have any intention of acting on or of inciting others to act on.

I can think of no belief a candidate might hold that is by itself conclusive reason to think he would misbehave on campus. Further reason to expect misbehavior, arising from other features of the candidate than his beliefs, is required if he is to be rejected as unsuitable on the ground of how he would act if he joined the faculty.

It is arguable, however, that the holders of certain beliefs may rightly be expected to try to produce effects on students of a kind we should be concerned about. Consider the nihilist about ethics, who believes that no moral judgment can be any better supported by reason than its negation can. On his view, the only "good" argument for a moral judgment is the argument that convinces, there being no room for the further question whether anyone ought to be convinced by it. Aren't we entitled to expect such a person to try to dampen, even extinguish, his students' interest in what makes a moral

14. See William W. Van Alstyne's amusing imaginary interview of an enemy of sociology (the candidate calls it "bullshit on stilts") who applies for a university"s position in sociology, Van Alstyne communication to the Committee on Academic Freedom and Tenure of the AAUP, in "Of Law and the River, " and Of Nihilism and Academic Freedom, $35 \mathrm{~J}$ Legal Educ 20 (1985). We certainly do not think institutional neutrality requires that it be open to each member of a department to include in or omit from his or her classes whatever he or she wishes. Typically, the members of a department jointly fix on the material that must be attended to by a student who concentrates in the department's discipline. They thereby jointly declare themselves on the substantive question of what constitutes work worthy of a certification of competence in the discipline. See note 9. 
argument really be good (as opposed to merely convincing)? Yes, because the nihilist about ethics precisely thinks that interest misguided.

The question is, however, whether trying to produce this effect is behaving unacceptably. Bullying and intimidation, misuse of classroom time, and incitement to interfere with political speech on campus are clear improprieties, but trying to dampen a student's interest in what makes a moral argument really be good (as opposed to merely convincing) is no impropriety if the nihilist about ethics is right, and there therefore isn't anything that makes a moral judgment really be good (as opposed to merely convincing). Moreover, it is no impropriety even if the nihilist is mistaken; if the nihilist is mistaken then he will have acted no more objectionably than has a scientist who in good faith, but mistakenly, dampens a student's interest in certain questions in biology or physics.

It might pay to stress too that the nihilist about ethics need not also be an amoralist, by which I mean a person who believes that no conduct is morally right and no conduct morally wrong. The nihilist about ethics may hold quite firm moral views: he may think much conduct morally right and much morally wrong entirely consistently with thinking (at the metaethical level) that his own moral views are not a product of reason. So the fact of his nihilism is not only not conclusive reason to think he will try to cause his students to act badly if it suits their fancy to do so, it is not even good reason to think he will try to do this.

Can things be thought otherwise in a professional school? What of the candidate for a position in a law school who is a legal nihilist? Does it make a difference that the position is in the university's law school as opposed to the university's department of philosophy? Dean Carrington suggests that it does. ${ }^{15}$ He suggests that the legal nihilist will dispirit his students, even disable them for the work for which they are being trained, and perhaps even encourage them to behave dishonestly in their later legal practice. He says that if a university takes on the responsibility of training professionals, it also accepts a duty to constrain teaching that will impede their capacity to do honorable professional work, so that while legal nihilism may well have a place elsewhere in the university, there is no room for it in a law school.

The charge that the legal nihilist will make dishonorable people of his students is surely overdrawn. The legal nihilist might also be an amoralist, but he need not be. Indeed, the particular legal nihilists who are Dean Carrington's targets are certainly not amoralists: they do have strong moral views-their work is positively drenched in moral indignation. The legal nihilist may well be a nihilist about ethics; according to some views of the relation between law and morality, it is not tenable to think morality rests on reason while law does not. But even if the legal nihilist is a nihilist about ethics, that is compatible with his rejecting amoralism.

15. Carrington, $34 \mathrm{~J}$ Leg Educ at 227 (cited in note 11 ). 
However, there isn't nothing in the charge that the legal nihilist will dispirit his students if he succeeds in convincing them of the truth of legal nihilism. For them to become convinced of the truth of legal nihilism is for them to become convinced that writing a brief and arguing a case are like writing commercials for soap powder: what counts is only whether you can construct an argument that will get the relevant audience to buy what you want them to buy. That leaves plenty of room for students to be trained in the skills required for selling their products successfully, so there is no reason to think their becoming convinced will disable them from the practice of law. But incoming law students typically think better than this of the profession they wish to become members of, and those who do will be dispirited. Some may even drop out.

Still, entering students in all parts of a university bring with them views it will dispirit them to discover the falsity of, and the fact that the discovery will dispirit them just is not by itself ground for their school to protect them against it-whether their school is the university's division of arts and sciences or one of its professional schools. If legal nihilism is false, then the students who are dispirited by it are mistakenly dispirited. But it can no more be thought proper for a professional school to protect its students against the possibility of mistaken dispiriting than for a biology or physics department to protect its students against the possibility of a similar mistake.

In short, nihilists cannot in general be rejected by reason of the effects they will try to produce in their students. Individual nihilists may rightly be expected to behave unacceptably on campus, not on the sheer ground of their being nihilists, but rather on the ground of whatever about them besides their nihilism gives reason to believe that they will behave unfairly, or will bully or intimidate, or misuse the classroom, this being possible in the case of nonnihilists as well.

\section{VI}

I asked whether there are any beliefs the having of which might by itself disqualify a candidate. We have considered the possibility that some beliefs are such that anyone who holds them may be expected to behave in unacceptable ways on campus. A second possibility is that some beliefs are such that we have good reason to think anyone who holds them is intellectually less than fully competent to occupy the position we wish to fill. This is surely true. Suppose a man applies for our position in mathematics and tells us at his interview that he's discovered a frightful mistake made by mathematicians: strictly speaking, $7+5=13$, and it's just good luck for us if our bridges don't fall down. He may be disqualified as a candidate on that ground alone. No doubt an institution of higher learning should be an intellectual experiment station, but some new ideas are self-contradictory.

A slightly less weird possibility is the candidate for our position in modern European history who tells us at his interview that there was no Holocaust. We may well think this belief absurd, but it is not self-contradictory. 
What is of interest in my description of this candidate is that the position for which he is a candidate is in modern European history. What if it were in chemistry? There would, presumably, be an impropriety in our dismissing his candidacy for a position in chemistry on the sheer ground of his believing there was no Holocaust. Why? Because his having that belief, however absurd we think it, presumably does not by itself show that he is less than intellectually competent to fill a position in chemistry-it does not by itself show anything about his ability to do research and teaching in chemistry. The fact that a candidate for a position in modern European history believes there was no Holocaust is another matter: we may well think that fact does give us ground for suspicions about his competence as a historian, for we may well think it shows he is incompetent at assessing historical evidence.

It is of course logically possible that he is right, for as I said, the idea that there was no Holocaust is not self-contradictory. (Contrast the belief that $7+$ $5=13$.) Moreover, it is logically possible not merely that he is right (as a matter of good luck), but also that he has good reason to believe that there was no Holocaust, good reason that we simply do not know of, indeed good enough reason to outweigh our reasons for believing that there was one, reason of a weight such that if we knew of it, we too would believe that there was no Holocaust. We may well think this highly unlikely, but it might be true. The question of his competence to occupy a position in history is therefore not conclusively settled by the fact that he believes there was no Holocaust. What his competence turns on is his reasons for holding that belief-his ability to justify it.

His ability to justify it to us. For what is to be said here is exactly the same as what is to be said in connection with the prior decision about what field to hire in: it is in light of our past experience with and in history that we must assess his competence for the position, that being exactly what a hiring committee is charged with doing. And we have a principled defense of our assessment just to the extent that we have exercised due care in arriving at it, and have made it on scholarly grounds, without excessive love of our own commitments.

The same holds for the varieties of nihilism. It is, after all, possible for the members of a given law faculty to think that legal nihilism, while no danger to the souls of the students, is nevertheless an absurd view, a person's holding of which is good reason to suspect him of intellectual deficiencies. (It is, after all, possible that they think, on the basis of careful study of the literature, that the arguments offered for legal nihilism have been dismal at best.) On some views, they should nevertheless invite a legal nihilist to join their faculty in order that this lively and active school of thought be presented to their students, and who more vividly to present it than a proponent of it? Perhaps they should. But it seems to me not at all obvious that they must. They might think that their educational mission is best carried out if they arrange for the presence in their offerings of all currently lively and active schools of legal thought, including those they think profoundly wrong-subject only to 
financial constraints. But must they think this? Or again, they might be modest: they might say to themselves, "Well, we are convinced it is profoundly wrong, but who are we? Maybe we are the ones who are profoundly wrong." But on any view of the matter, this modesty not only may but must have its limits. A faculty not only may but must settle on what constitutes student work that will earn the school's degree.

\section{VII}

We have canvassed two kinds of grounds on which a candidate's beliefs might give us reason to reject him. On the one hand, there is the reason his beliefs might give us to think he would misbehave on campus. There is no denying that some beliefs give reason to think this, but I suggested that the belief itself is not conclusive: the expectation of misbehavior may just be mistaken, and further evidence is required if the conclusion is to be justified. On the other hand, there is the reason a candidate's beliefs might give us to suspect him of intellectual incompetence. There is here too no denying that some beliefs do give reason to think this, but I suggested that (selfcontradictory beliefs apart) the fact of having the belief is not itself conclusive: the attribution of incompetence may just be mistaken, for incompetence lies in the candidate's reasons for holding the belief and not in the mere fact of his holding it.

Is there some further, third, kind of ground on which a candidate's beliefs might give us reason to reject him? I think not.

What makes this a difficult question, however, is the school sponsored by a particular religion. Suppose we are a school of theology within a Catholic university, and a candidate presents himself for our position in metaphysics and tells us he is an atheist. Or for our position in moral theology and tells us he believes there is nothing per se wrong in contraception or homosexuality. Will it do for us to reject him on ground of the sheer content of his beliefs?

Schools of theology can, and I think always do, say more than just "Look at the things he believes!" In the first place, we may think the candidate's holding those beliefs is reason to suspect him of intellectual deficiencies and thus of incompetence. Perhaps we think it perfectly clear to the eye of natural reason that there is a God and that contraception and homosexuality are per se wrong; and perhaps we think that the reasons the candidate offers us for rejecting these views are dismal at best. If so, then we are not rejecting him on ground of the sheer content of his beliefs.

Alternatively (or also), we may think his holding those beliefs is reason to expect him to misbehave on campus-we may think that he will misuse his classroom or refuse to present material we require our students to learn. But this expectation is suspect unless something more is forthcoming, for we would stand in need of reason-reason beyond the fact of his having those beliefs-for thinking that he in particular will misuse his classroom.

More interesting is the fact that we may expect him to dispirit, and not merely to dispirit but positively to disable our students. If our educational 
mission includes the training of Catholic priests, then if we hire this candidate, and he succeeds in convincing the students of his views, he will have rendered them incapable of engaging in an enterprise for which it is our educational mission to train them. This is a more serious charge than can be brought against the legal nihilist: if hired by the law school and then successful in his teaching, the legal nihilist will dispirit but not disable his students. I said that entering students in all divisions of a university bring with them views it will dispirit them to discover the falsity of, and that the fact that the discovery will dispirit them just is not by itself ground for their school to protect them against it, whether their school is the university's division of arts and sciences or one of its professional schools. But what of disabling our students? How could it not be open to us to reject those who would positively impede our carrying out of our educational mission?

This argument from disabling invites the reply that the educational mission of training priests had therefore better not be carried out within a university that lays claim to a place in the community of higher education. But is that right? Is it unacceptable for a university to lay such a claim if it has carved out an isolated corner within its walls for the training of priests? Even if it is in respect of all its other divisions a university like any other? (It is an interesting question why a religious group would want its priests trained within what is otherwise a university like any other. Why not operate independently, next door to the university? But I am sure that this question is not unanswerable.) On the other hand, what if the isolated corner were instead reserved for the training of propagandists for the advantages of a protective tariff? ${ }^{16}$ Does just anything go in just any corner, so long as its purpose is openly declared, and it is so far isolated as not to infect the rest? Or is religion special? I fancy that religion is special: that the university that carves out a corner for training priests does not show the disrespect for what a university is that is shown by the university in whose corners anything goes that can get itself funded. But I leave open what an argument for this view might look like.

What is plain, however, is that an argument from disabling would be markedly harder to make if the candidate I described were applying for a position in the university's division of arts and sciences as opposed to its school of theology. Students do not in general seem to be disabled by becoming convinced that there is no God or that there is nothing per se wrong in contraception and homosexuality. They will certainly be disabled from being Catholics if they become convinced of these things; but it is hard to see how a university could be thought to have a place in the community of higher education if its educational mission includes training its students to be Catholics.

16. I borrow this example from 1915 Declaration at 159; Appendix A at 394 (cited in note 1). 
These issues are difficult, however, and I have wished only to draw attention to them because they are so obviously among the issues that arise for us if we take the 1915 Declaration seriously. ${ }^{17}$

\section{VIII}

I have been concerning myself with ideological grounds for decisions on initial faculty selection, and have said nothing at all about procedures for making those decisions. In particular, I have throughout spoken of "we," and have left open who this "we" is. It is plain enough, however, that the faculty has a central role in such decisions, both in deciding about fields and in deciding among candidates: quite apart from the fact that the existing faculty may well be thought to have rights to a strong voice on such matters, there is the instrumental fact that faculty decision-making is likely to further the institution's purposes best. As I said, outsiders may be lucky enough to make successful choices, but if they do then that is mere luck.

However, an interesting problem arises at the intersection of the question what we are to think of ideological grounds for the decision-making and the question who is to do the decision-making, and I think it pays to have just a brief look at it. What $I$ have in mind is a problem that can arise when there is ideological inbreeding in a department. Imagine an extreme case. The Department of Dee at Upscale University is in Upscale's Division of Humanities, and all of the department's members profess adherence to X-ism, which is a particular movement within the discipline. (I hardly need say it is not for no reason that I suppose Dee to be a humanities subject.)

We can connect this with our topic if we suppose that Dee Department has a position to fill and that, after going through Upscale's established search procedures, it has just recommended to the appropriate institutional committee that Dr. Bloggs be appointed. Lo and behold, Bloggs is yet another $\mathrm{X}$-ist, and the supporting letters in his dossier are all from X-ists.

I am sure that this situation is already likely to make an administrator feel nervous. But with what justification? We can suppose it quite clear that there has been no bad faith in the department's decision-making: the members have throughout exercised due care, and have made their past and current decisions on scholarly grounds, without excessive love of their own commitments. They simply are convinced of the truth of X-ism: all anti-Xism in the discipline they would give you reason to think absurd, and all in the discipline that bypasses $\mathrm{X}$-ism they would give you reason to think benighted. Now, while academics generally believe that ideological diversity is a good

17. For some recent discussion of these issues within the AAUP. see Subcommittee of AAUP Committee A, The "Limitations" Clause in the 1970 Statement of Principles, 74 Academe 52 (SeptemberOctober 1988); Leon Pacala. Comments, 74 Academe at 57 (September-October 1988); William Van Alstyne, Comment, 74 Academe 58 (September-October 1988). See also the case report, Investigating Commitue of Committee A, Academic Freedom and Tenure: Catholic liniversity of America, 75 Academe 27 (September-October 1989); Comments from Counsel for the Administration of the Catholic University of America, 75 Academe 39 (September-October 1989); Michael W. McConnell, Academic Freedom in Religious Colleges and Lniversities, 53 L \& Contemp Probs 303 (Summer 1990). 
thing in a department, I know of none who would be prepared to license administrative enforcement of diversity on a department over its good-faith assurances that its ideological stance is correct.

Other things being equal, of course, for what if $\mathrm{X}$-ism is a battery of astrological theories? As I said earlier, it is the institution as a whole that awards the degrees on the recommendation of its faculty, and the faculty not only may but must take a stand on what student work is worth its degrees. So let us suppose that $\mathrm{X}$-ism is not a battery of theories for the study of which Upscale's faculty would be prepared to refuse academic credit out of hand. Then given the facts so far described, there seems to be nothing for the administration to do about the situation. In particular, nothing in the way of assessing Bloggs' candidacy by any procedure other than that normally followed at Upscale.

There is another way in which other things may fail to be equal, however. For let me now add some further details. Dee Department's graduate program has been sliding downhill steadily in the national rankings, despite healthy financial support from the university; no member of the department has won a major national fellowship in over a decade; the department has been receiving fewer and fewer applications to its graduate program and has been forced to accept more and more of them in order to fill its teaching assistantships; and it has been having increasing trouble finding teaching positions for its Ph.D.s who wish to teach. Members of the Dee discipline outside Upscale explain this phenomenon in this way: "The place is riddled with that loony $\mathrm{X}$-ism! Upscale's $\mathrm{X}$-ists are good X-ists, as X-ists go, but there's nowhere of interest that X-ists go."

How do the members of Upscale's Dee Department explain the phenomenon? They say in complete good faith that it issues from an anti-X-ist orthodoxy out there in the discipline, which prevents X-ism from getting a fair hearing, $\mathrm{X}$-ism (they say) is fifty years ahead of its time.

Why wasn't the situation attended to by the administration before things reached this pass? Let us suppose that Upscale has no visiting committee system and has a long tradition of allowing its departments a considerable measure of autonomy.

Must Upscale allow this situation to go on indefinitely? It won't do to reply that X-ism may after all be the truth about the discipline and that X-ism may really be fifty years ahead of its time. Any body of theory that is not selfcontradictory (including astrology) may turn out to be true. What makes trouble for the idea of taking action is not that X-ism may be true, but that the members of Dee Department are in good faith convinced that it is.

On the other hand, Upscale surely need not allow the situation to go on indefinitely. It is arguable, more strongly, that Upscale's administrators ought to intervene, and that they would be failing in an important administrative responsibility if they allowed Dee Department to carry on, business as usual.

The question what the administration can properly do is obviously a hard one. The question is no less hard if the administration is able to get non-Dee 
faculty cooperation in acting to constrain Dee Department. Faculty members cherish departmental autonomy, but they also place a high value on the status of their institution and therefore on the respectability of its programs; so nonDee faculty members may themselves be no less ready than their administration to act improperly against Dee Department. But I think we cannot deny that some course of action must be open to Upscale.

Does this commit us to the view that an administration may take action on substantive grounds? I think the answer may be yes. For I suggested that ideological inbreeding in a department is not something that would by itself justify administrative intervention, and what I think triggered the thought that some course of action must be open to Upscale's administrators is what I added when I told you that Dee Department has been sliding down the public disciplinary hill, and that those in the discipline at large attribute the phenomenon to its members' $\mathrm{X}$-ism. But how could adding that have made the difference? I think it may be only by way of its having given reason to think that X-ism is mistaken. For if the phenomenon could plausibly be explained in some way other than by appeal to a mistake in X-ism-if, for example, the phenomenon could plausibly be explained by personal prejudice against $\mathrm{X}$ ists-then wouldn't intervention be unacceptable? But to intervene on the ground that there is good reason to think X-ism mistaken is to intervene on a substantive ground.

In any case, suppose the administration does intervene and that $\mathrm{X}$-ism does not merely shrink at Upscale but gradually dies out as the current members of Dee Department retire. It might turn out that X-ism later takes over the discipline. Then X-ism really was ahead of its time! And Upscale's administrators have themselves made the mistake. It is worth stress that this no more shows they acted improperly in intervening than a similar mistake would show the faculty had acted improperly in making the kinds of decisions we looked at in earlier sections. Neither administration nor faculty is under a duty to be right, only to make a serious and fully responsible effort to be. ${ }^{18}$ draft.

18. I am grateful to Mary C. Potter and William W. Van Alstyne for comments on an earlier 